\title{
Yapı Malzemelerine Sürdürülebilir Mimarlık Bağlamında Bütüncül Bir Bakış: Duvar Malzemelerinin Çevresel Etkilerinin ve Enerji Performansının Belirlenmesi
}

\author{
Feride Çiğdem Kara ${ }^{1}$, Merve Tuna Kayıl1 ${ }^{2 *}$ \\ ${ }^{1}$ Karabük Üniversitesi, Lisansüstü Eğitim Enstitüsü, Mimarlık Anabilim Dalı, Karabük, Türkiye, (ORCID: 0000-0002-2876-7700), fcigdemkara@gmail.com \\ $2^{2 *}$ Karabük Üniversitesi, Mimarlık Fakültesi, Mimarlık Bölümü, Karabük, Türkiye, (ORCID: 0000-0002-3803-8229), mervetunakayili@karabuk.edu.tr
}

(İlk Geliş Tarihi 27 Ekim 2021 ve Kabul Tarihi 16 Aralık 2021)

(DOI: $10.31590 /$ ejosat.1015367)

\begin{abstract}
ATIF/REFERENCE: Kara, F. Ç. \& Tuna Kayıl1, M. (2021). Yapı Malzemelerine Sürdürülebilir Mimarlık Bağlamında Bütüncül Bir Bakış: Duvar Malzemelerinin Çevresel Etkilerinin ve Enerji Performansının Belirlenmesi, Avrupa Bilim ve Teknoloji Dergisi, (31), 583593.

$\ddot{O} \mathbf{z}$

Yapı sektörü malzeme ve enerji kaynaklarının büyük bir kısmını tüketirken, sektörün çevreye etkileri de tüketimle aynı oranda gerçekleşmektedir. Bu bağlamda, yapı malzemelerinin sürdürülebilirlik bağlamında ele alınması durumunda, hem enerji performansı hem de çevreye etkilerini ele alan bütüncül bir bakış açısıyla irdelenmesi, yapının tasarım evresinde gerçekleşen malzeme seçiminin daha doğru ve rasyonel olması için önemlidir. Çalışma kapsamında duvar konstrüksiyonlarında kullanılan tuğla, gazbeton ve bims bloğun çevresel etkileri ve yapının kullanım evresindeki enerji performasına ve kabuğun ısıl kütle özelliğine etkileri Safranbolu'da inşa edilmiş bir toplu konut projesi üzerinden irdelenmiş ve duvar malzemeleri sürdürülebilir mimarlık bağlamında bütüncül bir bakış açısıyla ele alınmıştır. Çalışma sonucunda, tuğlanın gazbeton ve bims bloğa göre üretim sürecindeki yüksek 1sı enerjisi gereksinimi nedeniyle çevresel etkileri daha fazla olmasına karşın yapının enerji performansını ve kabuğun ısı depolama kapasitesini artırdığı tespit edilmiştir.
\end{abstract}

Anahtar Kelimeler: Tuğla, Gazbeton, Bims blok, Çevresel etki, Enerji performansı, Isıl kütle

\section{A Holistic View on Building Materials in the Context of Sustainable Architecture: Determining the Environmental Impact and Energy Performance of Wall Materials}

\begin{abstract}
While the construction sector consumes a large part of material and energy resources, its effects on the environment occur at the same rate as consumption. In this context, if building materials are handled in the context of sustainability, it is important to examine both energy performance and environmental effects from a holistic perspective, so that the material selection realized during the design phase of the building is more accurate and rational. Within the scope of the study, the environmental effects of brick, aerated concrete and pumice block used in wall constructions and their effects on the energy performance of the building and the thermal mass of the shell were examined through a mass housing project built in Safranbolu and the wall materials were discussed from a holistic perspective in the context of sustainable architecture. As a result of the study, it has been determined that although the brick has more environmental effects due to the high heat energy requirement in the production process compared to aerated concrete and pumice blocks, it increases the energy performance of the building and the heat storage capacity of the shell.
\end{abstract}

Keywords: Brick, Aerated concrete, Pumice block, Environmental Impact, Energy performance, Thermal Mass

*Sorumlu Yazar: mervetunakayili@karabuk.edu.tr 


\section{Giriş}

Yapılar, malzeme kaynaklarının \%30'unu, enerji kaynaklarının \%40'ını tüketmekte ve $\mathrm{CO}_{2}$ salımının da \%36'sindan sorumlu tutulmaktadir (European Commission Energy Department, 2020). Bu bağlamda yap1 ve yap1 malzemeleri sürdürülebilirlik bağlamında ele alındığında, hem enerji tüketimi hem de çevresel etkileri içeren bütüncül bir bakış açısıyla irdelenmelidir. Binaların yapım sürecinde, malzeme çıkarım aşamasından başlanarak yapım, kullanım ve kullanım sonrası evreye kadar enerji tüketilmekle birlikte çevreye çeşitli açılardan zarar verilmektedir. Enerji analizlerinin ya da çevresel etkilerin tek başına ele alınması, tüm aşamalardaki tüketimleri ifade etmekte yetersiz kalmaktadır. Bu bağlamda, çevreye daha az zararlı kabul edilen bir malzemenin enerji performansının da göz önünde bulundurulması ile daha sürdürülebilir bir yaklaşıma kapı açmaktadir.

Yapıların çevresel etkilerinin değerlendirilmesi için kullanılan yaşam döngüsü değerlendirme (YDD) yöntemi, yapının tüm evrelerini detaylı olarak ele alan sistematik bir yöntemdir (Alkaya vd., 2012). Bu yöntem, yapı malzemelerinin hammadde çıkarım aşamasından başlayarak üretim, taşıma, kullanım süreci, ardından kullanım sonrası bertaraf edilme yöntemine kadar incelemektedir. Hava, su ve toprak kirlenmesini göz önüne alarak küresel ısınma, kaynakların tükenmesi, ozon tabakasının tahribi, ötrofikasyon, asidifikasyon ve zehirli salımlar gibi çeşitli çevresel etki kategorilerinde değerlendirme yapmaktadır (Özdemir, 2019). Yaşam döngüsü değerlendirme yöntemiyle bir konutun ele alınması, yapıyı oluşturan parçalarda üretim teknolojilerinin yanlış seçimi, doğal kaynakların bilinçsiz kullanımı, üretim ve yapımın çevrede atık yığınları oluşturması gibi meydana gelen çevresel etkilerini yapının her aşamasında ortaya koymaktadır (Tuna Taygun, 2005). Bu yöntemin kullanılması ile yapı malzemelerinin çevreye verdikleri zararın azaltılması ve çevresel etkisi daha az olan malzemelerin tercih edilmesi sağlanabilmektedir (Karaman Öztaş ve Tanaçan, 2015).

YDD yöntemi ile kalıplaşmış anlayışların yanlış olduğuna yönelik çarpıcı sonuçlar elde edilebilmektedir. Betonarme sistem ve ahşap iskelet sisteminin gömülü karbon değeri bakımından kıyaslandığı bir çalışmada, betonarme sistemin üretim evresinde daha yüksek gömülü karbon değeri tespit edilirken, yaşam boyu değerlendirme sonucunda gömülü karbonu \%34 değerinde azalttığı belirtilmektedir (Monahan ve Powell, 2011). Yine yün halı ile naylon halının çevresel etkilerinin karşılaştırıldığı bir çalışmada, yün halının üretim sürecinde kullanılan yüksek ağartıcılar nedeniyle naylon halıya göre daha fazla çevresel etkiye sahip olduğu tespit edilmektedir (Tuna Kayılı ve Çelebi, 2015). Ayrıca kullanım evresinde ise iç mekân hava kalitesinin artırılmasına yönelik, iç mekân kirleticilerini absorblama özelliği nedeniyle yün halının tercih edilmesi gerektiği belirtilmektedir (Katsoyiannis vd., 2006).

Yapının enerji performansı da çevresel etkilerle birlikte göz önünde bulundurulması gereken bir konudur. Atmosfere salınan sera gazının \%50'sinden binalarda kullanılan enerji tüketimi sorumlu tutulmaktadır (UNFCCC, 2020). Duvar/pencere oran1, yönlenme, camlı yüzeylerin güneşten yararlanma oranı gibi parametrelerin yanı sıra yapılarda kabuk bileşenlerinin 1S1 iletkenlik değerlerinin azaltılması ile yapının ısıtma ve soğutma yükünün azaltılması mümkündür (URL 1). Yalıtımsız farklı duvar konstrüksiyonları, benzer enerji performans sonuçları vermekle birlikte, dolu tuğla, hafif tuğla, gazbeton içeren farklı duvar e-ISSN: 2148-2683 kesitlerine yalıtım eklenerek 1sı kayıplarının azaltılmasıyla enerji performansının iyileştirilebildiği bilinmektedir (Sezer ve Dilmaç, 2014).

Yapılarda seçilen malzemelerin 1sı depolama özellikleri de yapının 1sıl kütle kullanımı açısından önemlidir. Taş, tuğla ve beton gibi ağır konstrüksiyon malzemeleri yüksek 1sı depolama kapasiteleri nedeniyle yapıda uygulandiklarında, 1sıl kütleden kaynaklanan faz erteleme ve genlik küçültme özelliği sayesinde yapının 1s1l konforunun devam ettirilmesinde ve enerji performansının artırılmasında önemli bir katkı sağlamaktadır (Konuklu ve Paksoy, 2011). Bu anlamda malzemelerin 1sil ve çevresel anlamda bütüncül olarak ele alınması, yapının kullanım evresindeki enerji kullanımının ve çevresel etkilerinin azaltılması açısından çok önemlidir. Yapının çevresel etkilerinin belirlenmesinde, kullanım evresindeki enerji performansını etkileyen tasarım kararlarının rolü büyüktür. Bu bağlamda tasarım evresinde malzeme seçimi yapılırken, çevresel etkileri ile birlikte kullanım evresindeki enerji performansına etkisi de göz önünde bulundurulmalıdır.

Yapılarda çevresel etki ve enerji performansının bütüncül bir bakışla ele alındığı çalışmalar mevcuttur. Yeşil cephe ve yeşil duvar sistemlerinin yapının çevresel ve enerji performasına etkisinin araştırıldı ̆̆ çalışma (Chàfer vd., 2021), kenaf bitkisinin sürdürülebilir bir yalıtım malzemesi alternatifi olarak ve bu malzemenin enerji performansı ve çevresel etkilerinin sunulduğu çalışma (Ardente vd., 2008), sürdürülebilir bir yap1 inşası için 6 farklı pasif tasarım senaryosunun enerji kullanımı ve çevresel etki bağlamında değerlendirildiği çalışma (Tushar vd., 2021) bu anlamda öne çıkan çalışmalar olarak sayılabilmektedir. Pasif evlerin çevresel etkilerinin kanıtlanmış olduğu kabul edilip kullanıcı etkilerinin enerji performansına katkılarını ele alan çalışma (Peuportier vd., 2013) olduğu gibi, enerji performansı ve çevresel etkiyi içeren bu bütüncül bakış açısının sürdürülebilir bina tasarımı için bir karar verme aracı olarak görülebileceğini belirten (Chau vd., 2015) çalışmalar da bulunmaktadır. Yapıda enerji performansı ve çevresel etkilerin değerlendirilmesinin yanı sıra, yapının kent içerisindeki sosyolojik konumunu da ele alarak mevcut yapiların ve gelecekte tasarlanacak yapıların iyileştirilmesi için bina performansının disiplinlerarası daha geniş bir ölçekte ele alındığı çalışma (Pannier vd., 2021) da bulunmaktadir.

Türkiye'de yapılarda çevresel etki ve enerji performansı değerlendirme çalışmaları incelendiğinde, bu iki etkinin bir arada ele alınmasından ziyade bir konuya odaklanan çalışmalara rastlanmaktadır (Yıldız vd., 2008; Özutku ve Karakuş; Yıldız, vd., 2011). YDD üzerine yapılan çalışmalar Türkiye'de genellikle literatür taraması olarak karşımıza çıkmaktadır. Bunun en önemli sebebi ise Türkiye'de yaşam döngüsü değerlendirme çalışmaları için veri eksikliğinden kaynaklanmaktadır (Benli Yıldız vd., 2020). Yaşam döngüsü veri araçlarından daha gerçekçi sonuçlar elde edilebilmesi için yapı malzemelerinin üretim sektörüne daha yakın veriler içermesi gerekmektedir (Rajagopalan vd., 2010).

Yaşam döngüsü değerlendirme yönteminin malzeme ölçeğinde ele alındığı çalışmalar incelendiğinde, yalıtım malzemesi üzerinde oldukça durulduğu görülmektedir (Llantoy vd., 2020; Ata-Ali vd., 2021; Dylewski ve Adamczyk, 2013). Son zamanlarda sürdürülebilirlik kavramının önem kazanmasıyla, yaşam döngüsü değerlendirme çalışmaları artış göstermiştir (Colangelo vd., 2021; Ding, 2013; Bianco vd., 2021; Hossain vd., 2017; Manjunatha vd.,2021). Bunun yanısira cephe kaplama malzemeleri (Hesser, 2015; La Rosa vd., 2021; Y1lmaz vd., 2019); 
yol kaplama malzemeleri (Thiel vd., 2013; Bai vd., 2021; Jullien vd., 2019), cam (Salazar, 2013), stabilize killi malzemeler (Marcelino-Sadaba vd., 2017), çelik ve ahşap strüktür üzerine (Morris vd., 2021; Wu vd., 2020) birçok çalışma yapıllmıştır.

Duvar malzemeleri üzerine yapılan çalışmalar incelendiğinde, iç mekân bölücü duvarları üzerine yapılan bir çalışmada duvar malzemeleri olan tuğla, bims ve alçıpan ile oluşturulan duvarların A1-A5 evrelerinde çevresel etkileri karşılaştırılarak incelenmiştir. Elde edilen sonuçlarda alçıpanın çelik saplama malzemeleri nedeniyle en yüksek çevresel etkiye sahip olduğu görülmüştür. Ayrıca bimste kullanılan çimentonun, tuğlada kullanılan pişirme işleminin çevresel etkileri arttırdığ sonucuna ulaşılmıştır (Valencia-Barba vd., 2019). İç mekân bölücü duvarları üzerine yapılan bir çalışmada 44 ayrı duvarın A1-A5 evrelerindeki duvar katmanlarının çevresel etkileri incelenmiştir. Oluşturulan alternatiflerde akustik yalıtım, 1sı yalıtımı, yangına dayanıklılık ve mekanik dayanım gibi parametreler göz önünde bulundurulmuştur. Elde edilen sonuçlarda duvar yapım malzemesinin \%48 ile en büyük etki değerine sahip olduğu oranı tespit edilmiştir (Valencia-Barba vd., 2021). Çalışmalardan elde edilen sonuçlar duvar yapım malzemesinin tasarım aşamasında doğru seçiminin yapının çevresel etkisinin azaltılmasındaki önemini ortaya çıkmaktadır.

$\mathrm{Bu}$ bağlamda yapılan çalışmada, duvar malzemelerinin çevresel etkilerinin belirlenmesi ve seçilen malzemelerin yapının kullanım evresindeki enerji performansına etkisinin tespit edilmesi hedeflenmiştir. Malzemelerin çevre ve enerji performansına etkilerinin belirlenmesi, Safranbolu TOKİ konutları üzerinden gerçekleştirilmiştir. Çalışmanın özgün değeri tuğla, gazbeton ve bims malzemelerinin çevresel ve enerji performanslarını bütüncül olarak ele almasıdır. Elde edilen sonuçların mimarlara, malzeme üreticilerine ve karar vericilere yapının tasarım evresinde malzeme seçimi bağlamında yol gösterici olması beklenmektedir.

\section{Materyal ve Metot}

\subsection{Duvar Malzemeleri}

Çalışma kapsamında duvar dolgu malzemeleri olan tuğla, gazbeton ve bims bloğun çevresel ve yapının enerji performansına etkileri konut birimi üzerinden belirlenmiştir. Duvar konstrüksiyonlarının oluşturulmasında seçilen duvar malzemelerinin özellikleri Tablo 1'de verilmiştir.

Tablo 1. Seçilen duvar malzemelerinin özellikleri

\begin{tabular}{l|c|c}
\hline Malzemeler & $\begin{array}{c}\text { Isıl İletkenlik } \\
\text { Hesap Değeri } \\
\text { W/(m.K) }\end{array}$ & $\begin{array}{c}\text { Yoğunluk } \\
\left(\mathbf{k g} / \mathbf{m}^{\mathbf{3})}\right.\end{array}$ \\
\hline Bims & 0.23 & 1070 \\
Tuğla & 0.54 & 1550 \\
Gazbeton & 0.21 & 580 \\
\hline
\end{tabular}

Çalışmada seçilen malzemelerin aynı koşullarda çevresel etkilerinin belirlenmesine yönelik ihtiyaç duyulan duvar katmanı için Safranbolu Kirkille TOKİ konutları seçilmiştir. Aynı ısı iletim katsayısına sahip duvar konstrüksiyonunda yer alan tuğla, gazbeton ve bims bloğun çevresel etki değerleri karşılaştırılmıştır.

\subsection{TOKİ Konutları}

Duvar malzemelerinin çevresel ve enerji performansına etkilerinin belirlenebilmesi için Safranbolu Kirkille TOKI konutları seçilmiştir. Çalışmada toplu konut yapısının seçilme nedeni, toplu konutların yüksek inşa edilme oranları ve geleceğe dönük yapı iyileştirmelerinde ön sırada (Ingrao vd., 2018) yer almalaridır.

Karabük'ün Safranbolu ilçesinde yer alan Kirkille TOKI konutlarının yapımı 2019 yılında tamamlanmıştır. Yöresel mimariye uyumlu olma amacı taşıyan bu yapılar (Şekil 1), 2+1 ve $3+1$ olarak inşa edilmiştir. 579 konuttan 417'si 2+1, 162'si 3+1 olması sebebiyle, bu çalışmada $2+1$ daire ele alınmıştır. Ele alınan daire $79.80 \mathrm{~m}^{2}$ brüt alana sahip olup, şematik kat planı Şekil 2'de verilmiştir.

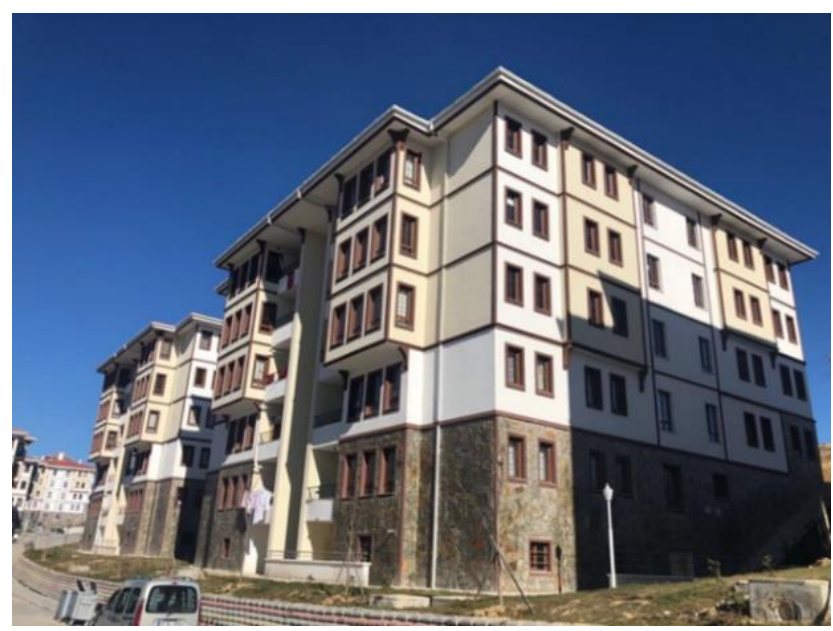

Şekil 1. Safranbolu Kirkille TOKİ toplu konutları (URL 2)

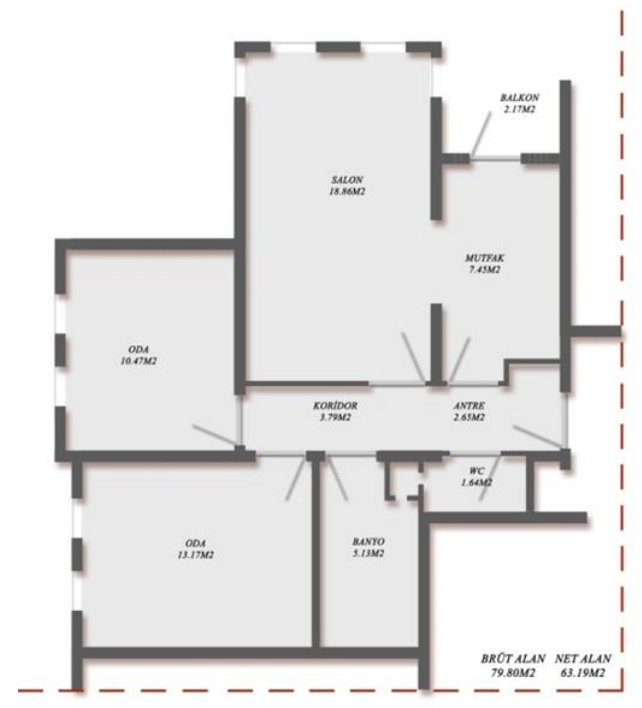

Şekil 2. Kısmi plan şeması

Konutların inşa aşamasında duvar malzemesi olarak bims blok kullanılmıştır. Çalışmada yapının mevcut duvar konstrüksiyonuna alternatif olarak gazbeton ve tuğla ile oluşturulan konstrüksiyonlar önerilmiş ve karşılaştırma yapılmıştır. Yapının duvar katmanlarını gösteren grafik Şekil 3 'te verilmiştir. 


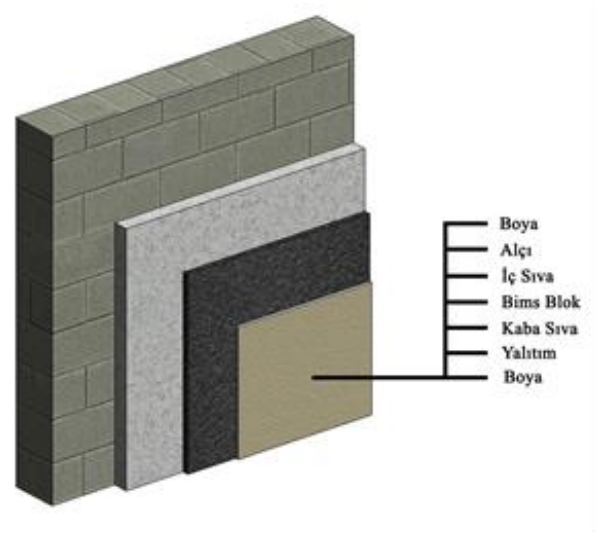

Şekil 3. Mevcut duvar katmanları (Bims blok)

\subsection{Duvar Malzemelerinin Kalınlığına Karar Verilmesi}

Seçili duvar malzemelerinin çevresel performansının belirlenmesinde kalınlığın rolü büyüktür. $\mathrm{Bu}$ bağlamda performans hesaplamalarında aynı 1sı iletkenlik değerine sahip duvar katmanlarının değerlendirilmesine karar verilmiş, dolgu malzemesi dişında kalan diğer katmanlar sabit tutulup duvar dolgu malzemeleri çeşitlendirilmiştir. Bu bağlamda, Şekil 3 'te verilen mevcut duvar katmanları üzerinden kabuğun 1s1 iletim katsayısı (U değeri) TS 825'te belirtilen Eşitlik 1 ve 2 yardımıyla hesaplanmış ve $1 \mathrm{~s}$ i iletim katsayısı $0.27 \mathrm{~W} / \mathrm{m}^{2} \mathrm{~K}$ olarak belirlenmiştir. Karabük ili Safranbolu ilçesi 3. Derece gün bölgesinde yer aldığından, belirlenen değerin TS825'e göre önerilen duvar 1sı iletim katsayısına uygun olduğu tespit edilmiştir. $\mathrm{Bu}$ nedenle tuğla ve gazbetondan oluşturulacak alternatif duvarlar için de 1 sı iletim katsayısı $0.27 \mathrm{~W} / \mathrm{m}^{2} \mathrm{~K}$ olacak şekilde oluşturulmuş, tuğla ve gazbeton dışında kalan katmanların kalınlıkları her duvarda sabit kalacak şekilde düzenlenmiştir. Düzenlenen alternatif duvarlara ait grafikler Şekil 4 ve 5 'te, katman kalınlıkları ise Tablo 2'de verilmiştir.

$$
R=(\mathrm{d} 1 / \lambda \mathrm{h} 1)+(\mathrm{d} 2 / \lambda \mathrm{h} 2)+\cdots . .+(\mathrm{dn} / \lambda \mathrm{hn})
$$

$\mathrm{Bu}$ eşitlikte;

$\mathrm{R}=$ Çok tabakalı yapı bileşenlerinde 1 sıl geçirgenlik direnci $\mathrm{d}_{1}, \mathrm{~d}_{2}, \ldots, \mathrm{d}_{\mathrm{n}}=$ Yapı malzemesi kalınlıkları

$\left(\lambda_{\mathrm{h} 1}, \lambda_{\mathrm{h} 2}, \ldots, \lambda_{\mathrm{hn}}\right)=$ Yap1 malzemelerinin 1 s1l iletkenlik hesap değerleri

$$
U=1 / R
$$

$\mathrm{Bu}$ eşitlikte;

$\mathrm{U}=$ Yapı bileşeninin toplam 1sıl geçirgenlik katsayısı

$\mathrm{R}=$ Çok tabakalı yapı bileşenlerinde 1 sıl geçirgenlik direnci

Tablo 2. Duvar malzemelerinin kalınlıklarl

\begin{tabular}{l|c|c|c}
\hline Malzemeler & $\begin{array}{c}\text { Isıl İletkenlik } \\
\text { Hesap Değeri } \\
\text { W/(m.K) }\end{array}$ & $\begin{array}{c}\text { Kalınlık } \\
\text { (m) }\end{array}$ & $\begin{array}{c}\text { Yoğunluk } \\
\left(\mathbf{k g} / \mathbf{m}^{\mathbf{3}}\right.\end{array}$ \\
\hline Bims & 0.23 & 0.20 & 1070 \\
Tuğla & 0.54 & 0.47 & 1550 \\
Gazbeton & 0.21 & 0.18 & 580 \\
\hline
\end{tabular}

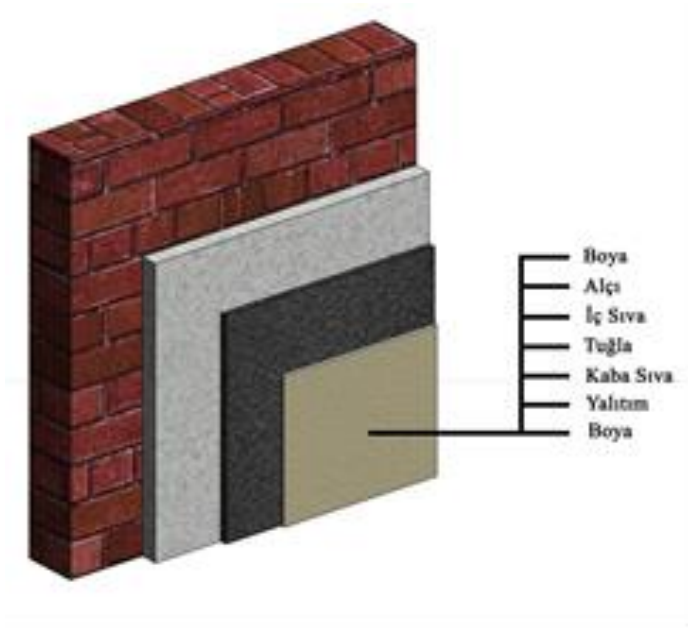

Şekil 4. Tuğla ile oluşturulan duvar katmanları

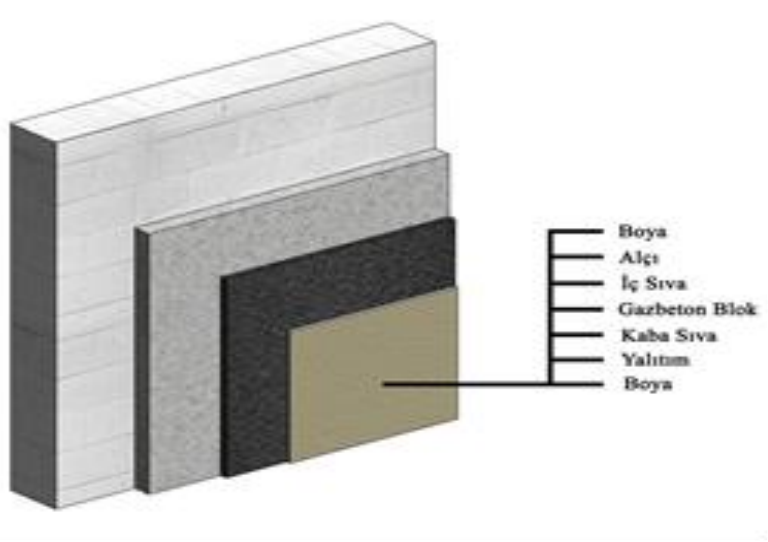

Şekil 5. Gazbeton ile oluşturulan duvar katmanlar

\subsection{Duvar Malzemelerinin YDD Yöntemi ile Çevresel Etkilerinin Belirlenmesi}

Duvar malzemelerinin çevresel etkilerinin belirlenmesinde YDD yöntemi kullanılmıştır. Yöntemi kullanırken, yapı Autodesk Revit Architecture programında modellenmiş (Şekil 6) ve çevresel etkisinin belirlenmesinde Tally eklentisi çalıştırılmıştır (Şekil 7). Tally GaBi veritabanı üzerinden çalışan, yapının beşikten mezara tüm evrelerinin çevresel etkilerini ortaya koyabilen bir arayüz olup, Autodesk Revit programı ile birlikte sıklıkla tercih edilip, hızlı sonuç verebilen bir yaşam döngüsü değerlendirme aracıdır (Najjar vd., 2017; Bueno ve Fabrico, 2018; Hasik vd., 2019; Tushar vd., 2021; Raposo vd., 2019).

Tuğla, gazbeton ve bims bloğun çevresel etkilerinin belirlenmesinde seçilen ișlevsel birim ve hizmet ömürleri Tablo 3'te verilmiştir. YDD yöntemi ile bütün duvar konstrüksiyonlarının çevresel etkileri belirlenmiş ve konstrüksiyonu oluşturan malzemelerin ayrı ayrı çevresel etki değerlerine ulaşılmıştır. Bu bağlamda seçilen tuğla, gazbeton ve bimsblok duvar malzemelerinin duvar konstrüksiyonunun çevresel etki değerindeki katkısı da Şekil 9-13'te belirtilmiştir.

Tablo 3. Duvar malzemelerine yönelik YDD kriterleri

\begin{tabular}{l|c|c}
\hline & $\begin{array}{c}\text { Hizmet } \\
\text { Ömrü (yıl) }\end{array}$ & $\begin{array}{c}\text { İşlevsel } \\
\text { Birim }\end{array}$ \\
\hline Malzemeler & 60 & $\mathrm{~m}^{2}$ \\
\hline
\end{tabular}

Duvar malzemelerinin çevresel etkilerinin belirlenmesinde A1-A3 evreleri olan ürün evresi ile inşaat evresinin A4 evresi ele 586 
alınmıştır (Şekil 8). Çalışmaya A4 evresinin eklenme nedeni, çevresel etki değerlendirmelerinde ürünün şantiyeye taşınması evresinin göz ardı edilmesi durumunda büyük oranda çevresel etki görmezden gelinebilmekte (Murmu ve Patel, 2018; Buyle vd., 2013), ayrıca yüksek nakliye giderleri ile karşılaşılabilmektedir. $\mathrm{Bu}$ nedenle çevresel etki değerlendirmelerinde A4 evresinin özellikle ele alınması gerekmektedir.

Yap1 malzemelerinin A4 evresindeki çevresel etkileri, ürünlerin şantiye evresine getirilmesinde oluşan $\mathrm{CO}_{2}$ salımı ve enerji tüketimi bağlamında değerlendirilmiştir. Malzemelerin üretim alanına taşınması sırasında gerekli enerji ve bu işlem sonucunda ortaya çıkan $\mathrm{CO}_{2}$ salım değeri EN 16258'e göre EcoTransit World (Ecological Transport 62 Information Tool for Worldwide Transports) çevrimiçi hesaplama aracı kullanılarak belirlenmiştir (ecotransit.org, 2016). Malzemelerin fabrikadan şantiye alanına getirilmesinde kabul edilen fabrikalar ve uzaklıkları Tablo 4'te verilmiştir.

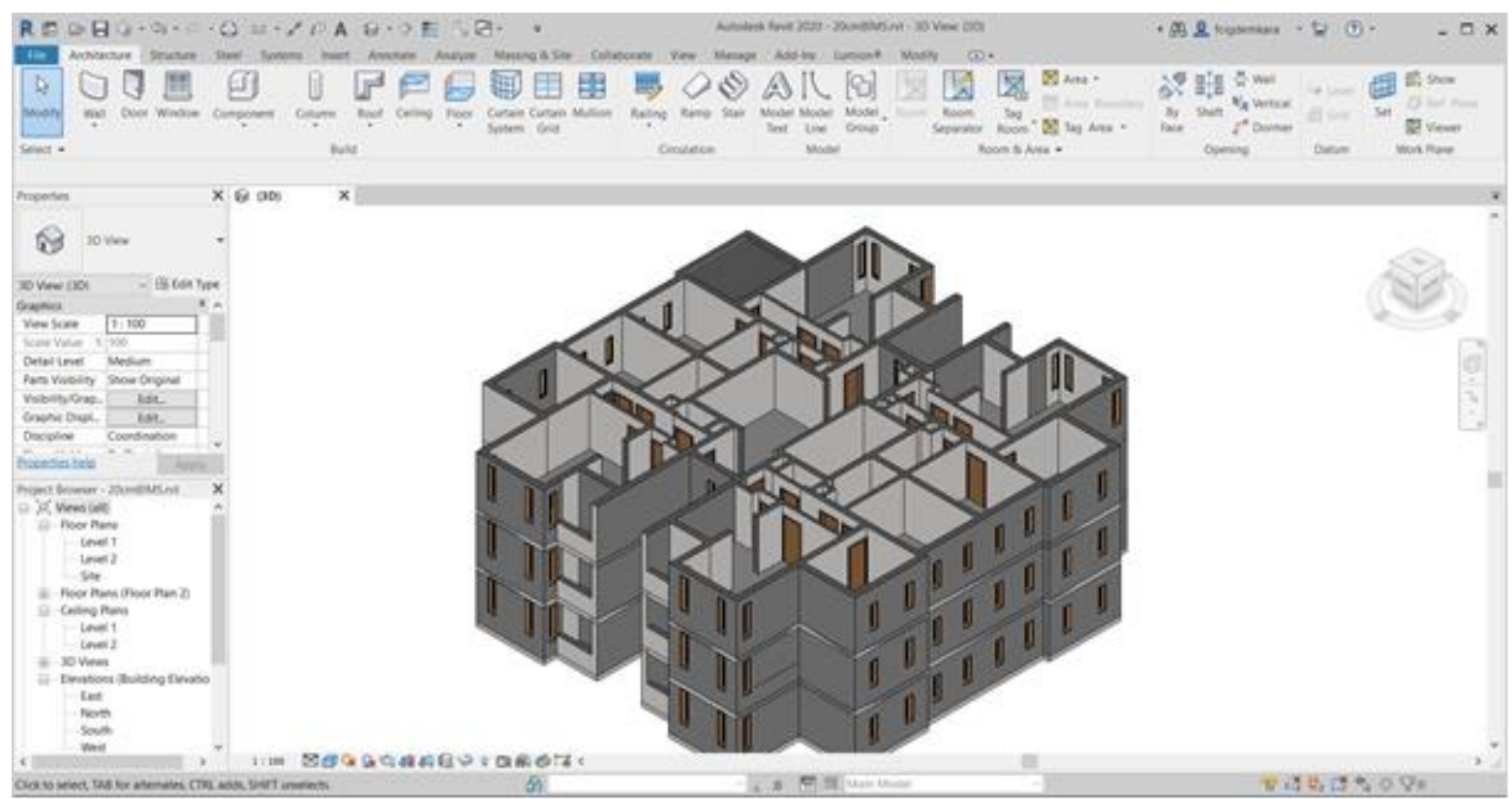

Şekil 6. Yapının Autodesk Revit Architecture programında modellenmesi

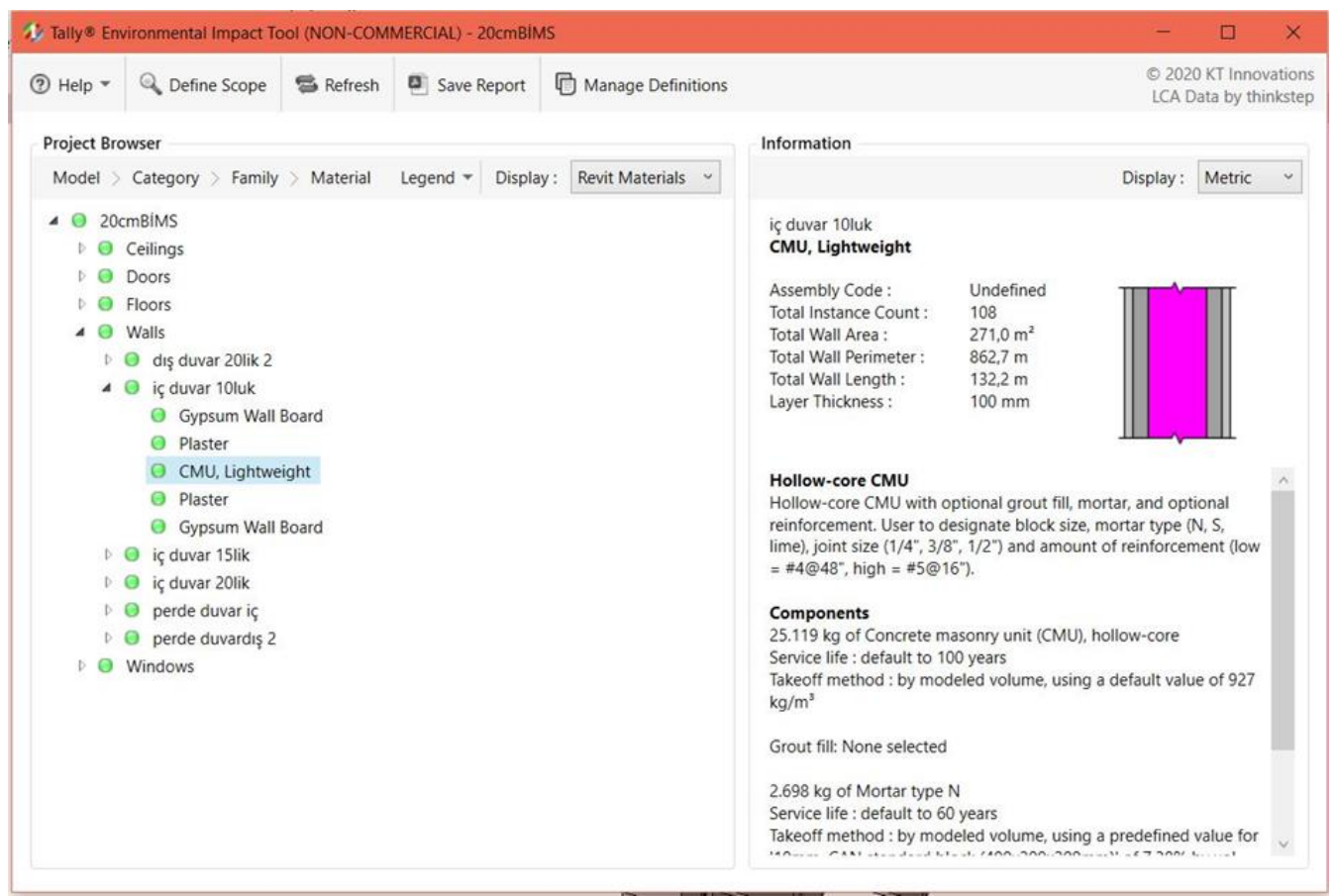

Şekil 7. Autodesk Revit Architecture programı Tally eklentisi arayüzü 


\begin{tabular}{|c|c|c|c|c|c|c|c|c|c|c|c|c|c|c|c|c|}
\hline \multirow{2}{*}{\multicolumn{3}{|c|}{$\begin{array}{c}\text { A 1-3 } \\
\text { Ürün Evresi }\end{array}$}} & \multicolumn{2}{|c|}{ A 4-5 } & \multicolumn{7}{|c|}{ B 1-7 } & \multicolumn{4}{|c|}{ C 1-4 } & \multirow{3}{*}{ D } \\
\hline$-^{\text {Üri }}$ & & & $\begin{array}{r}\text { Ins: } \\
- \text { Ever }\end{array}$ & & & & & anım & Evre & & & & $\mathrm{am} \mathrm{Sc}$ & nu Ev & resi & \\
\hline A1 & $\mathrm{A} 2$ & $\mathrm{~A} 3$ & A4 & A5 & B1 & B2 & B3 & B4 & B5 & B6 & B7 & C1 & $\mathrm{C} 2$ & $\mathrm{C} 3$ & $\mathrm{C} 4$ & \\
\hline 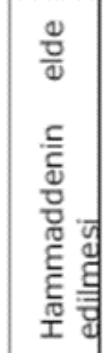 & $\begin{array}{l}\frac{E}{\bar{U}} \\
\frac{\pi}{5}\end{array}$ & 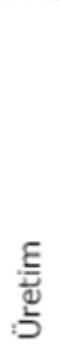 & $\frac{E}{\bar{J}}$ & 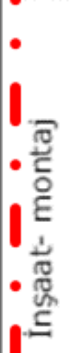 & 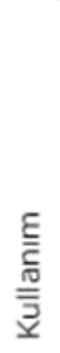 & $\frac{\xi}{\frac{\xi}{\tilde{D}}}$ & 党 & 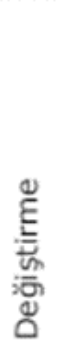 & 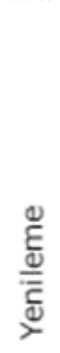 & 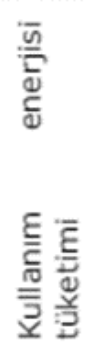 & 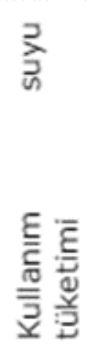 & $\frac{\xi}{\frac{\varepsilon}{\nu}}$ & 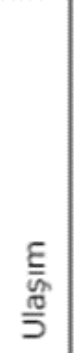 & 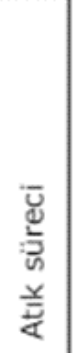 & 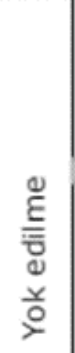 & $\begin{array}{c}\text { Sistem } \\
\text { sınırları } \\
\text { dişındaki } \\
\text { avantajlar ve } \\
\text { yükler } \\
\text { (yeniden } \\
\text { kullanım, geri } \\
\text { kazanma ve } \\
\text { geri dönüšüm } \\
\text { potansiveli) }\end{array}$ \\
\hline
\end{tabular}

Şekil 8. Çalışmada ele alınan yaşam döngüsü değerlendirme evreleri

Tablo 4. Duvar malzemelerinin varsayılan temin yeri ve mesafeleri

\begin{tabular}{l|c|c|c}
\hline Malzemeler & Şehir & Firma & Mesafe \\
\hline Tuğla & Bartın & Iş1klar Tuğla & $78.4 \mathrm{~km}$ \\
Bims & Ankara & KRS Blok & $203 \mathrm{~km}$ \\
Gazbeton & Kirıkkale & AKG Gazbeton & $249 \mathrm{~km}$ \\
\hline
\end{tabular}

YDD'de TRACI 2.1 karakterizasyon şeması seçilmiştir. Bu şemada malzemelerin;

- Küresel isınma potansiyeli,

- Asidifikasyon potansiyeli,

- Ötrofikasyon potansiyeli,

- Fotokimyasal ozon gazı oluşumu,

- Ozon tabakasının tahribatı tespit edilebilmektedir.

\subsection{Duvar Malzemelerinin Yapının Enerji Performansına Etkisinin Belirlenmesi}

Duvar malzemelerinin yapının enerji performansına etkisi Design Builder programı kullanılarak belirlenmiştir. Bu alandaki gelişmiş ve güncel yazılımlardan biri olan ve ısıtma ve soğutma sistemlerini simüle eden Design Builder yazılımı binanın 1sıtma, soğutma, aydınlatma, ev aletleri, su tüketimi gibi farklı enerji kullanımlarını dinamik olarak modelleme yeteneğine sahiptir (Tindale, 2005).

Duvar malzemelerinin yapının 1sıl kütlesine etkisinin belirlenmesinde EN ISO 13786'e göre hesaplama yapan HTflux ısıl kütle hesaplama aracı kullanılmıştır. HTflux, 1sı ve su buharı taşınımının iki boyutlu simülasyonu için kullanılan bir yazılımdır. HTflux tarafindan geliştirilen bir yöntem olan GLASER 2d, bilinen ve kanıtlanmış Glaser yöntemini iki boyutlu geometrilere uygulayarak simülasyonlar oluşturulmasına olanak sağlamaktadır (URL 3).

\section{Bulgular}

$\mathrm{Bu}$ bölümde duvar konstrüksyonlarının ve seçilen duvar malzemelerinin çevresel etki değerleri ve yapının enerji performansına etkisi verilmiştir.

\subsection{Duvar Malzemelerinin Çevresel Etki Değerleri}

Çalışmada seçilen duvar malzemelerinin çevresel etkileri ve içinde yer aldığı duvar konstrüksiyonlarının çevresel etki değerlerindeki pay1, ürün evresi (A1-A3) ve ulaşım evresi (A4) evresi olmak üzere ayrı ayrı verilmiştir.

\subsubsection{A1-A3 Evresi}

Küresel iklim değişikliği, uzun dönemli sıcaklık, yağış, rüzgâr gibi iklimsel faktörlerin değişimi olarak tanımlanmaktadır. Küresel ısınma, küresel iklim değişikliğinin bir çeşidi olmakla birlikte yüzeye yakın havanın ve okyanusların ortalama sıcaklığının da artmasıdır (Calkins, 2009). Küresel ısınmaya sera gazları neden olmaktadır. Sera gazları karbondioksit $\left(\mathrm{CO}_{2}\right)$, metan $\left(\mathrm{CH}_{4}\right)$, azotoksit $\left(\mathrm{NO}_{\mathrm{x}}\right)$, ozon $\left(\mathrm{O}_{3}\right)$, sülfürhekzaflorit $\left(\mathrm{SF}_{6}\right)$, hidroflorokarbon (HFC), perklorokarbon ve kloroflorokarbonlar (CFC) olarak sayılabilmektedir. Ayrıca doğrudan küresel 1sınmaya etkisi olmayan gazlar indirekt etkiyle yeryüzeyindeki ve stratosforik ozondaki sera gazı formunu etkilemektedir. Bunlar ise karbon monoksit $(\mathrm{CO})$, azotoksitler $\left(\mathrm{NO}_{\mathrm{x}}\right)$ ve $\mathrm{CH}_{4}$ içermeyen uçucu organik bileşiklerdir (NMVOCs). Fosil yakıtlar, yüksek basınç altında oluştuklarından karbondioksit içeriği yüksek yakıtlardır. Bu yakıtların kullanımı sonucunda büyük oranda $\mathrm{CO}_{2}$ ve sera gazları açığa çıkmakta ve atmosfere karışmaktadır.

Tuğla, gazbeton ve bims bloktan oluşturulan duvar konstrüksiyonlarının A1-A3 evresindeki çevresel etki değerleri incelendiğinde, Şekil 9'da görülebileceği gibi en yüksek küresel ısınma potansiyeline sahip duvar konstrüksiyonunun tuğla duvar konstrüksiyonu olduğu ve tuğlanın etki değerinin konstrüksiyonun etki değerindeki payının \%53.31 olduğu tespit edilmiştir. Aynı 1sı iletkenlik değerine $\left(0.27 \mathrm{~W} / \mathrm{m}^{2} \mathrm{~K}\right)$ sahip duvar konstrüksiyonları içinde en düşük küresel ısınma potansiyeline sahip duvar konstrüksiyonu ise bims blok duvar konstrüksiyonudur. Konstrüksiyonun etki değerinde en az payı (\%10.76) olan malzeme ise yine bims bloktur. Gazbetonun küresel 1sınmada duvar konstrüksiyonu içerisindeki payı \%20.92'dir. Tuğlanın üretimi esnasında açığa çıkan karbon salımlarının diğer duvar malzemelerine göre fazla olması, üretim sürecinde yüksek 1sı enerjisi gerektirmesi ve bu enerjinin de fosil yakıtlardan sağlanması ile açıklanabilmektedir.

Asitleşme, sülfür ve nitrojen (asit gazları) bileşiklerinin suda çözünmesiyle su yüzeyine geçmesi ya da katı parçaçıklar halinde toprağa bağlanmasıyla oluşmaktadır. Bu bileşikler ilk olarak asit yağmurları şeklinde kuru ya da ıslak çökelme sürecinde ekosisteme ulaşmaktadır (Calkins, 2009). Büyük şehirlerdeki çok sayıda motorlu araçtan çıkan azot oksit salımları, fosil yakıt kullanımı, volkanlar ya da çürüyen bitki örtüsünden salınan sülfürdioksit ya da nitrojenoksit gazları da asit birikimine katkı yapmaktadır (Selici vd., 2005). 


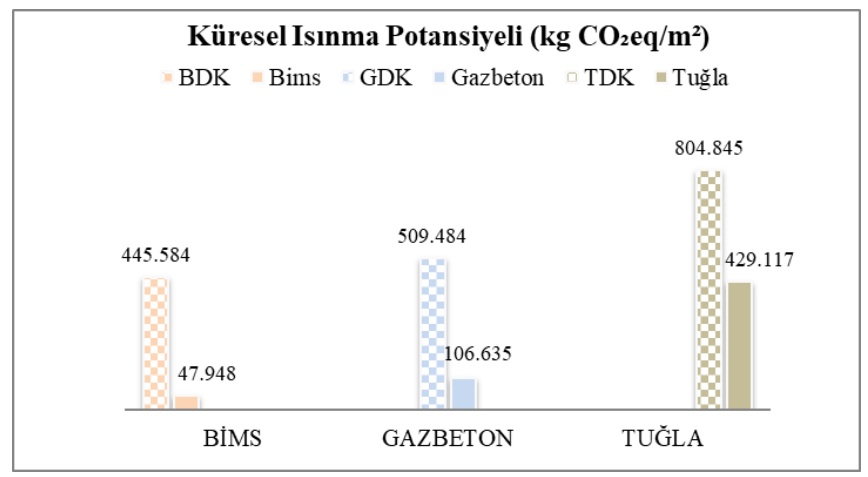

Şekil 9. Duvar konstrüksiyonları ve seçilen duvar malzemelerinin küresel ısınma potansiyeli

Şekil 10'da görülebileceği gibi en yüksek asidifikasyon potansiyeline sahip duvar konstrüksiyonunun tuğla duvar konstrüksiyonu olduğu ve tuğlanın etki değerinin konstrüksiyonun etki değerindeki payının \%47.61 olduğu tespit edilmiştir. Duvar konstrüksiyonları, asidifikasyon potansiyeli özelinde etki değeri büyükten küçüğe doğru tuğla, gazbeton ve bimsblok duvar konstrüksiyonu olarak siralanabilmektedir. Gazbeton ve bimsbloğun asidifikasyon potansiyelinde duvar konstrüksiyonu içerisindeki payı sırasıyla \%12.32 ve \%10.48'dir. Tuğlanın üretimi esnasında açığa çıkan asit gazlarının diğer duvar malzemelerine göre fazla olması, asidifikasyon potansiyelinde olduğu gibi üretim sürecinde yüksek 1sı enerjisi gerektirmesi ve bu enerjinin de fosil yakıtlardan sağlanması ile açıklanabilmektedir.

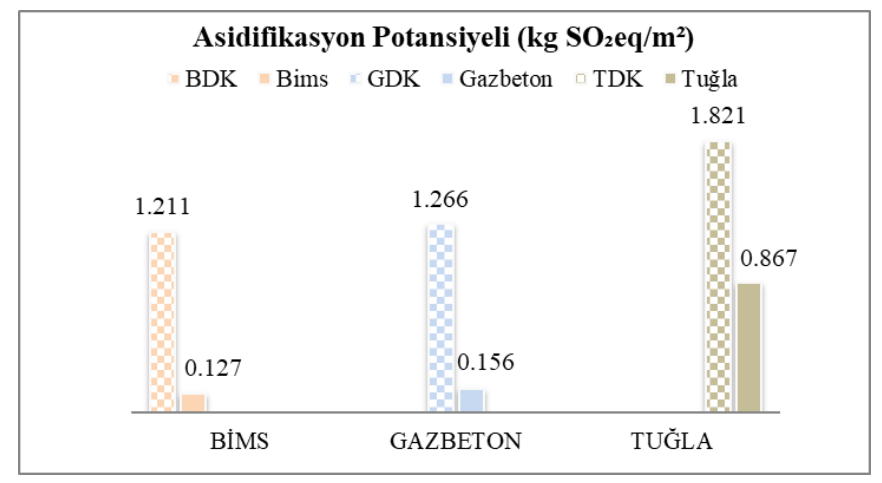

Şekil 10. Duvar konstrüksiyonlarl ve seçilen duvar malzemelerinin asidifikasyon potansiyeli

Ötrofikasyon tatlı suların besin maddesi açısından zenginleşmesi ve bitki hayatının yüksek oranda gelişmesi ile sudaki ekolojik dengenin bozulması olarak tanımlanabilmektedir. Sinırlayıcı nütrient fosfor $(\mathrm{P})$ ve antropojenik kaynaklardan bu elementlerin tatlı sulara geçişi, göllerin doğal yaşlanma sürecini hızlandırmaktadır. Bununla birlikte gelişen algler çözünmüş oksijeni önemli ölçüde tüketerek diğer canlıların ölümüne yol açabilmektedir (Kondalkar vd., 2019; Fan vd., 2019; Çiftçi ve Arslanoğlu, 2021).

Şekil 11'de görülebileceği gibi duvar konstrüksiyonları ötrofikasyon potansiyeli özelinde incelendiğnde, etki değeri büyükten küçüğe doğru tuğla, gazbeton ve bimsblok duvar konstrüksiyonu olarak siralanabilmektedir. Konstrüksiyonun etki değerinde en fazla payı (\%46.07) olan malzeme ise yine tuğladır. Gazbeton ve bims bloğun ötrofikasyon potansiyelinde duvar konstrüksiyonu içerisindeki payı sırasıyla \%15.49 ve \%11.76'dır.

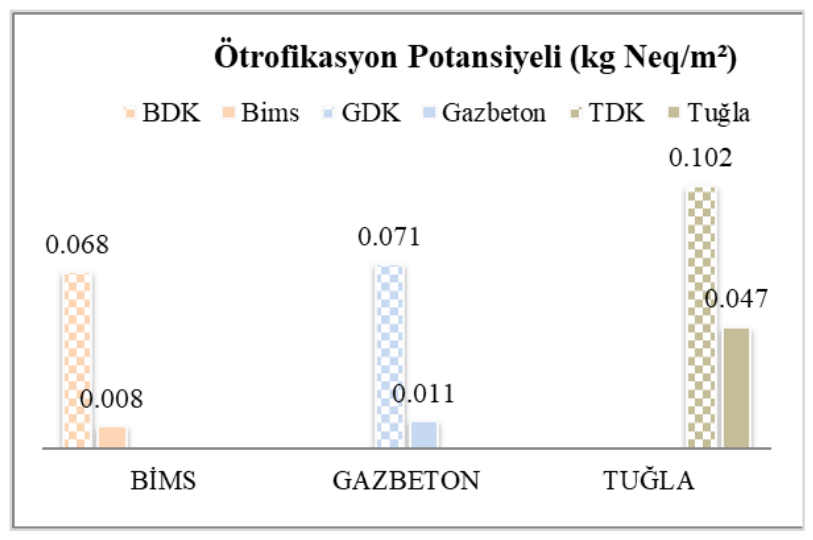

Şekil 11. Duvar konstrüksiyonlart ve seçilen duvar malzemelerinin ötrofikasyon potansiyeli

Atmosferdeki fotokimyasal reaksiyonlar güneş radyasyonunun başlangıcından itibaren farklı zamanlarda farklı aşamalarda seyretmektedir. Kent üzerinde sabah inversiyonunun etkisiyle yükselememiş hidrokarbonlar, azot oksitler, metalik tozlar gibi hava kirleticiler bakımından zengin hava kütlesinde kızıl-kahve renkli bir sis oluşmaktadır. Bu sis fotokimyasal ozon olarak tanımlanmaktadır. Araç egzozları, endüstriyel salımların oluşturduğu uçucu organik bileşikler ve nitrojen oksitlerin havaya karışmasıyla fotokimyasal ozon oluşmaktadır (Özcan vd. 2006).

Şekil 12'de görülebileceği gibi en yüksek fotokimyasal ozon gazı oluşturma potansiyeline sahip duvar konstrüksiyonunun tuğla duvar konstrüksiyonu olduğu ve tuğlanın etki değerinin konstrüksiyonun etki değerindeki payının \%51.39 olduğu tespit edilmiştir. Duvar konstrüksiyonları içinde en düşük fotokimyasal ozon gazı oluşturma potansiyeline sahip duvar konstrüksiyonu ise bims blok duvar konstrüksiyonudur. Konstrüksiyonun etki değerinde en az payı (\%13.81) olan malzeme ise yine bims bloktur. Gazbetonun fotokimyasal ozon gazı oluşturmada duvar konstrüksiyonu içerisindeki payı \%14.65'tir. Tuğlanın üretimi esnasında açığa çıkan endüstriyel hava kirleticilerinin diğer duvar malzemelerine göre fazla olması ile açıklanabilmektedir.

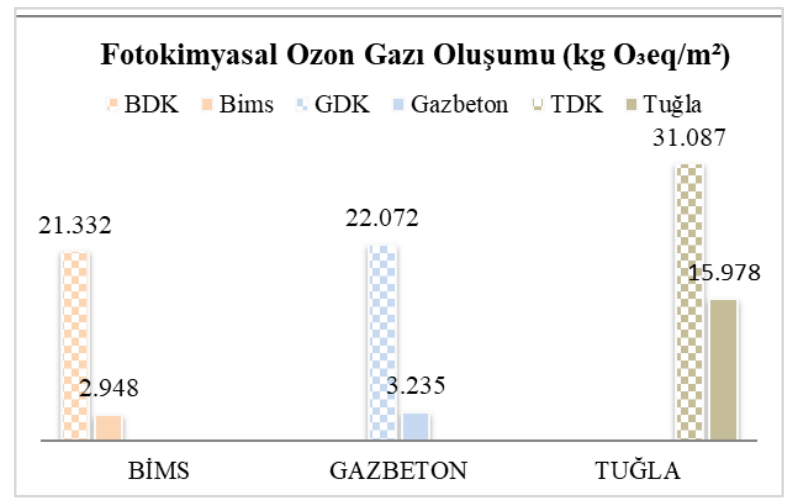

Şekil 12. Duvar konstrüksiyonları ve seçilen duvar malzemelerinin fotokimyasal ozon gazı oluşturma potansiyeli

Stratosferik ozon yüksek atmosferde, stratosfer tabakasında bulunmakta ve güneşten gelen zararlı ultraviyole ışınlarını emerek, bu ışınların olumsuz etkilerini ortadan kaldırdığından iyi huylu ozon olarak bilinmektedir (http://dmi.gov.tr). Kloroflourokarbon (CFC) gazı içeren spreyler, deodorantlar, böcek öldürücüleri vb. gibi bileşikler, stratosfere kadar bozulmadan çıkarak kutuplara doğru yayılıp ozonla reaksiyona girerek ozonun konsantrasyonunu düşürmektedir. Böylece kutuplar üzerindeki ozon tabakasında yırtılmalar meydana gelmektedir. 
Şekil 13 'te görülebileceği gibi en yüksek ozon tabakasının tahribine sebep olabilecek duvar konstrüksiyonunun tuğla duvar konstrüksiyonu olduğu ve tuğlanın etki değerinin konstrüksiyonun etki değerindeki payının $\% 0.48$ olduğu tespit edilmiştir. Duvar konstrüksiyonları içinde en düşük ozon tabakasının tahribine neden olabilecek duvar konstrüksiyonu ise gazbeton blok duvar konstrüksiyonudur. Konstrüksiyonun etki değerinde en az payı $(\% 0.005)$ olan malzeme ise yine gazbeton bloktur. Bims bloğun ozon tabakasının tüketiminde duvar konstrüksiyonu içerisindeki payı \%0.04'tür.

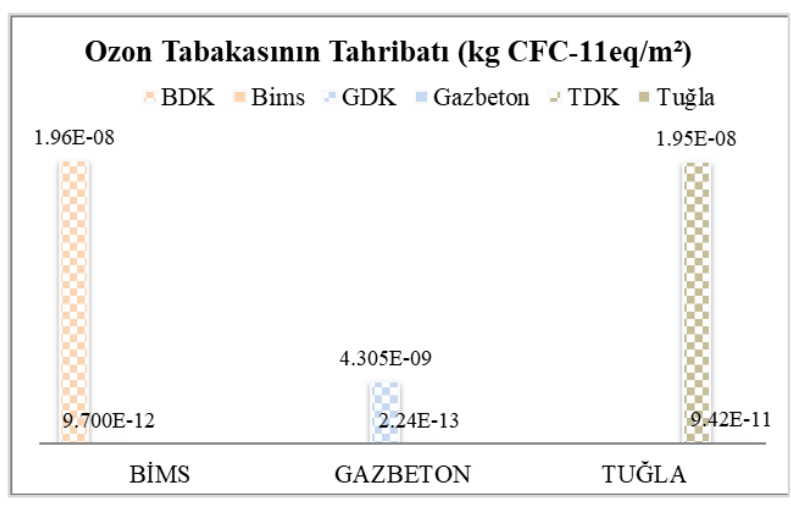

Şekil 13. Duvar konstrüksiyonları ve seçilen duvar malzemelerinin ozon tabakasi tahribatı potansiyeli

\subsubsection{A4 Evresi}

Duvar malzemelerinin A4 evresinde (ürünün şantiye evresine nakliyesi) oluşan enerji tüketimi ve $\mathrm{CO}_{2}$ salım değerleri Tablo 4'te verilen ulaşım verileri dikkate alınarak hesaplanmıştır. Ürünlerin A4 evresi için gerekli olan enerji miktarı tuğla, gazbeton ve bims blok için sırasiyla $8091 \mathrm{MJ}, 24225 \mathrm{MJ}$ ve $31575 \mathrm{MJ}, \mathrm{CO}_{2}$ salımları ise $0.6,2,2$ ton olarak belirlenmiştir. Şantiye alanına en uzak mesafede ürün temin yeri bulunan gazbeton, beklendiği gibi ulaşım için gerekli olan enerji tüketiminde ve $\mathrm{CO}_{2}$ salımında ilk sırada yer almıştır (Şekil 14,15).

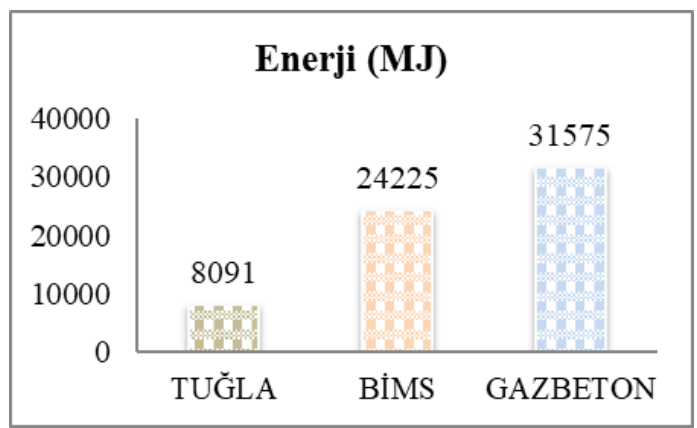

Şekil 14. Seçilen duvar malzemelerinin A4 evresi enerji tüketimi

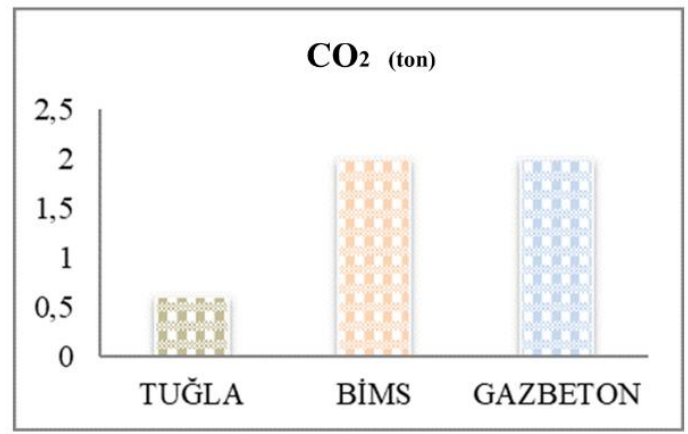

Şekil 15. Seçilen duvar malzemelerinin A4 evresinde ortaya çıkan $\mathrm{CO}_{2}$ salım değerleri

\subsection{Duvar Malzemelerinin Yapının Enerji Performasına Etkisi}

$\mathrm{Bu}$ bölümde duvar malzemelerinin yapının enerji performansına ve kabuğun isıl kütle özelliğine etkisi ele alınmıştır.

\subsubsection{Enerji Performansına Etkisi}

Tuğla, gazbeton ve bims blok ile oluşturulan konstrüksiyonlar TOKİ konutları için Design Builder yazılımında analiz edilmiş ve konutun 1sıtma ve soğutma ihtiyacı için yıllık enerji ihtiyacı belirlenmiştir. Tablo 5 'te görülebileceği gibi, tuğla konstrüksiyon duvar ile üretilen konutun enerji ihtiyacı $178.28 \mathrm{kWh} / \mathrm{m}^{2}$ ve bims blok konstrüksiyon duvar ile üretilen konutun enerji ihtiyac1 $197.47 \mathrm{kWh} / \mathrm{m}^{2}$ iken, gazbeton blok konstrüksiyon duvar ile üretilen konutun enerji ihtiyac1 $200.51 \mathrm{kWh} / \mathrm{m}^{2}$ olarak hesaplanmıştır (Şekil 16) Aynı duvar 1sı iletkenlik değerine sahip olmasına rağmen tuğlanın yüksek isı depolama yeteneği sayesinde enerji ihtiyacını azalttığı söylenebilmektedir (Tablo 6).

Tablo 5. Seçili duvar malzemeleri ile oluşturulmuş yapının enerji ihtiyacı

\begin{tabular}{l|c|c|c}
\hline Konstrüksiyon & $\begin{array}{c}\text { Isıtma } \\
\left(\mathbf{k W h} / \mathbf{m}^{\mathbf{2}}\right)\end{array}$ & $\begin{array}{c}\text { Soğutma } \\
\left(\mathbf{k W h} / \mathbf{m}^{\mathbf{2}}\right)\end{array}$ & $\begin{array}{c}\text { Toplam } \\
\left(\mathbf{k W h} / \mathbf{m}^{\mathbf{2}}\right)\end{array}$ \\
\hline Tuğla & 140.52 & 37.76 & 178.28 \\
Bims & 153.06 & 44.41 & 197.47 \\
Gazbeton & 155.27 & 45.24 & 200.51 \\
\hline
\end{tabular}

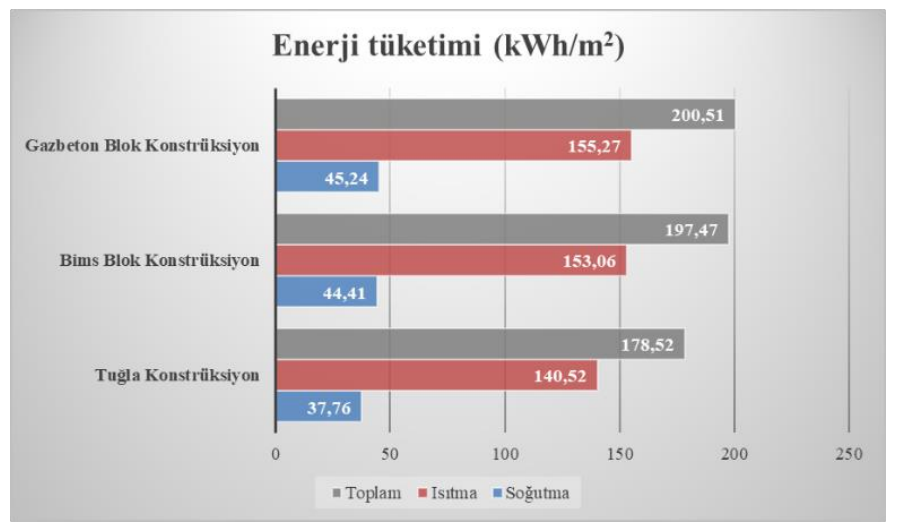

Şekil 16. Seçili duvar malzemeleri ile oluşturulmuş yapının enerji tüketimi

\subsubsection{Kabuğun ısıl kütle özelliğine etkisi}

Tuğla, gazbeton ve bims bloğun kabuğun 1sıl kütlesine etkisi değerlendirildiğinde, Tablo 6'da da görülebileceği gibi tuğlanın iç alan 1s1 kapasitesinin $52.958 \mathrm{~kJ} /\left(\mathrm{m}^{2} . \mathrm{K}\right)$, bims bloğun 48.059 $\mathrm{kJ} /\left(\mathrm{m}^{2} . \mathrm{K}\right)$, gazbetonun ise $45.844 \mathrm{~kJ} /\left(\mathrm{m}^{2} . \mathrm{K}\right)$ olduğu hesaplanmıştır. Tuğla konstrüksiyonun daha fazla isı depolama kapasitesi sayesinde, 1sıl kütle üzerinde etkili olduğu söylenebilmektedir. Bu bağlamda, faz erteleme süresinin en uzun ve genlik küçültme faktörünün en yüksek olduğu konstrüksiyon tipi tuğla konstrüksiyondur. Yüksek 1sıl kütleye sahip konstrüksiyon tipi, iç mekanın ısıl konforunun sağlanmasında enerji ihtiyacını düşürerek olumlu etki sağlamaktadır. 
Tablo 6. Konstrüksiyonların isı depolama kapasiteleri

\begin{tabular}{|c|c|c|c|}
\hline Konstrüksiyon & $\begin{array}{l}\text { İç alan ıSı } \\
\text { kapasitesi } \\
\mathbf{k J} /\left(\mathbf{m}^{2} . \mathbf{K}\right)\end{array}$ & $\begin{array}{l}\text { Dış alan ısı } \\
\text { kapasitesi } \\
\mathrm{kJ} /\left(\mathrm{m}^{2} . \mathrm{K}\right)\end{array}$ & $\begin{array}{l}\text { Toplam ISı } \\
\text { kapasitesi } \\
\mathrm{kJ} /\left(\mathbf{m}^{2} . \mathbf{K}\right) \\
\end{array}$ \\
\hline Tuğla & 52.958 & 5.267 & 58.225 \\
\hline Bims & 48.059 & 5.625 & 53.684 \\
\hline Gazbeton & 45.844 & 6.005 & 51.849 \\
\hline
\end{tabular}

\section{Sonuç ve Öneriler}

Çalışma kapsamında duvar konstrüksiyonlarında kullanılan tuğla, gazbeton ve bims bloğun çevresel etkileri ve yapının kullanım evresindeki enerji performasına ve kabuğun 1sıl kütle özelliğine etkileri sürdürülebilir mimarlık bağlamında bütüncül bir bakış açısıyla ele alınmıştır. Duvar malzemelerinin çevresel etkileri TRACI 2.1 karakterizasyon şeması üzerinden ayrı ayrı etki sınıflarınca ele alınmıştır. Elde edilen veriler tuğlanın çevresel etkilerinin üretim sürecinde yüksek 1 s1 enerjisi gerektirdiğinden gazbeton ve bims bloğa göre daha fazla olduğunu göstermektedir. Örnek alan olarak seçilen Safranbolu Kirkille TOKİ Konutları için tuğlanın Safranbolu'ya yakın olan Bartın'daki tuğla fabrikasından temin edileceği düşünüldüğünde, diğer malzemelerin tedariğine göre A4 evresindeki enerji tüketimi ve $\mathrm{CO}_{2}$ salımı da en azdır.

Duvar malzemelerinin konutun enerji performansına etkisi incelendiğinde en düşük 1sıtma ve soğutma yükünün tuğla konstrüksiyon ile inşa edilen konutta olduğu hesaplanırken, en yüksek 1sı depolama kapasitesine sahip kabuk ise yine tuğladadır.

Yapının inşa edileceği arazi koşulları, makro ve mikroklimatik iklim koşulları, kullanım sıklığı ve ısıtma düzeni yap1 kabuğunda kullanılacak malzeme seçimini birincil olarak etkilemektedir. Öyle ki, sıcak kuru veya soğuk iklim koşullarında inşa edilecek bir yapı için enerji tüketimi ve ısıl kütle önemli bir parametre iken, kesikli 1sıtma ve kullanım düzenine sahip bir yap1 için yapının hafif konstrüksiyon ile hızlı ısınması öne çıkabilmektedir. Fakat malzemelerin her evrede düşük çevresel etki değerlerine sahip olması beklenmektedir. Malzemelerde düşük çevresel etki, yüksek enerji ve ısıl performansın yolu ise yenilenebilir enerji kaynaklarının üretim sürecine dahil edilmesi ve malzemenin kullanım evresi sona erdiğinde geri dönüşüm yöntemleri ile atık yönetiminin kurgulanmasından geçmektedir. Fosil yakıtarın neden olduğu çevresel etkiler bu yolla azaltılabilecek, temiz enerji kaynakları ile üretilen yapı malzemeleri geri dönüştürülerek hammadde ihtiyacının önüne geçilebilecektir.

Çalışmanın ilerleyen evrelerinde, farklı işleve sahip yapı türleri için malzemelerin etkileri üzerinde durularak, farklı makro ve mikroklimatik iklim koşullarındaki durumlarının tespit edilmesi planlanmaktadır.

\section{Kaynakça}

Alkaya, E., Böğürcü, M. \& Ulutai, F. (2012). Yaşam Döngüsü Analizi ve Bina Isı Yalıtım Malzemeleri İçin Uygulamalar. Çevre Bilim \& Teknoloji, 3(4) 4, 261-274.

Ardente, F., Beccali, M., Cellura, M., \& Mistretta, M. (2008). Building energy performance: A LCA case study of kenaffibres insulation board. Energy and Buildings, 40(1), 1-10. https://doi.org/10.1016/j.enbuild.2006.12.009
Ata-Ali, N., Penadés-Plà, V., Martínez-Muñoz, D., \& Yepes, V. (2021). Recycled versus non-recycled insulation alternatives: LCA analysis for different climatic conditions in Spain. Resources, Conservation and Recycling, 175 https://doi.org/10.1016/j.resconrec.2021.105838

Bai, T., Mao, B., Chen, A., Li, Y., Wu, S., Hu, Z., \& Lin, Z. (2021). Investigation of low-temperature construction additives (LCAs) effects on the technical properties of asphalt binder. Construction and Building Materials, 304(February). https://doi.org/10.1016/j.conbuildmat.2021.124634

Benli Yıldız, N., Arslan, H., \& Yılmaz, E. (2020). Life Cycle Assessment of Building Materials: Literature Rewiew. Düzce Üniversitesi Bilim ve Teknoloji Dergisi, 8, 210-219.

Bueno, C., \& Fabricio, M. M. (2018). Comparative analysis between a complete LCA study and results from a BIM-LCA plug-in. Automation in Construction, 90 (January 2016), 188-200. https://doi.org/10.1016/j.autcon.2018.02.028

Buyle, M., Braet, J., \& Audenaert, A., (2013). İnşaat Sektöründe Yaşam Döngüsü Değerlendirmesi: Bir İnceleme. Yenilenebilir ve Sürdürülebilir Enerjiler Üzerine İncelemeler, Antwerp, Belçika, vol. 26, ss. 379-388, Oct.

Calkins, M. (2009). Materials for sustainable sites: a complete guide to the evaluation, selection, and use of sustainable construction materials. Hoboken, NJ: John Wiley \& Sons. $457 \mathrm{p}$.

Chàfer, M., Pérez, G., Coma, J., \& Cabeza, L. F. (2021). A comparative life cycle assessment between green walls and green facades in the Mediterranean continental climate. Energy and Buildings, 249. https://doi.org/10.1016/j.enbuild.2021.111236

Chau, C. K., Leung, T. M., \& Ng, W. Y. (2015). A review on Life Cycle Assessment, Life Cycle Energy Assessment and Life Cycle Carbon Emissions Assessment on buildings. 143, 395413. https://doi.org/10.1016/j.apenergy.2015.01.023

Colangelo, F., Farina, I., Travaglioni, M., Salzano, C., Cioffi, R., \& Petrillo, A. (2021). Eco-efficient industrial waste recycling for the manufacturing of fibre reinforced innovative geopolymer mortars: Integrated waste management and green product development through LCA. Journal of Cleaner $\begin{array}{ll}\text { Production, } & 312 \text { (May), }\end{array}$ https://doi.org/10.1016/j.jclepro.2021.127777

Çiftçi, H., \& Arslanoğlu, H. (2021)Çinko Üretimi Atık Kekinin Fosfat Adsorpsiyon Özelliklerinin İncelenmesi. Bilecik Şeyh Edebali Üniversitesi Fen Bilimleri Dergisi, 8(1), 251-262.

https://doi.org/10.35193/bseufbd.878902

Ding, G. K. C. (2013). Life cycle assessment (LCA) of sustainable building materials: An overview. Eco-Efficient Construction and Building Materials: Life Cycle Assessment (LCA), EcoLabelling and Case Studies, 38-62. https://doi.org/10.1533/9780857097729.1.38

DMİ, “Stratosferik Ozon Tükenimi”, http://dmi.gov.tr (2010).

Dylewski, R., \& Adamczyk, J. (2013). Life cycle assessment (LCA) of building thermal insulation materials. In EcoEfficient Construction and Building Materials: Life Cycle Assessment (LCA), Eco-Labelling and Case Studies. 
Woodhead Publishing Limited. https://doi.org/10.1533/9780857097729.2.267

European Commission Energy Department (2021) "In focus: Energy efficiency in buildings", [pdf] Energy Department, Brussels, Available at: https://ec.europa.eu/info/sites/default/files/energy_climate c c hange environment/events/documents/in focus energy effi ciency in buildings_en.pdf [Erişim tarihi: 25.09.2021]

Fan, R., Chen, C. L., Lin, J. Y., Tzeng, J. H., Huang, C. P., Dong, C. \& Huang, C. P. (2019). Adsorption characteristics of ammonium ion onto hydrous biochars in dilute aqueous solutions. Bioresource technology, 272, 465-472.

https://doi.org/10.1016/j.biortech.2018.10.064

Hasik, V., Escott, E., Bates, R., Carlisle, S., Faircloth, B., \& Bilec, M. M. (2019). Comparative whole-building life cycle assessment of renovation and new construction. Building and Environment, 161(May), 106218. https://doi.org/10.1016/j.buildenv.2019.106218

Hesser, F. (2015). Environmental advantage by choice: Ex-ante LCA for a new Kraft pulp fibre reinforced polypropylene composite in comparison to reference materials. Composites Part B: Engineering, 79, 197-203. https://doi.org/10.1016/j.compositesb.2015.04.038

Hossain, M. U., Poon, C. S., Lo, I. M. C., \& Cheng, J. C. P. (2017). Comparative LCA on using waste materials in the cement industry: A Hong Kong case study. Resources, Conservation and Recycling, 120, 199-208. https://doi.org/10.1016/j.resconrec.2016.12.012

Ingrao, C., Messineo, A., Beltramo, R., Yigitcanlar, T., \& Ioppolo, G. (2018). How can life cycle thinking support sustainability of buildings? Investigating life cycle assessment applications for energy efficiency and environmental performance. Journal of Cleaner Production, 201, 556-569. https://doi.org/10.1016/j.jclepro.2018.08.080

Jullien, A., Proust, C., \& Yazoghli-Marzouk, O. (2019). LCA of alternative granular materials - Assessment of ecotoxicity and toxicty for road case studies. Construction and Building Materials, 227, 116737. https://doi.org/10.1016/j.conbuildmat.2019.116737

Katsoyiannis, A.. Leva, A. P \& Kotzias, D. (2006)Determination of Volatile Organic Compounds Emitted from Household Products. The Case of Velvet Carpets Fresenius Environ. Bull., 15, (8b) 943-949, 2006.

Kondalkar, M., Fegade, U., Attarde, S. \& Ingle, S. (2019). Phosphate removal, mechanism, and adsorption properties of Fe-Mn-Zn oxide trimetal alloy nanocomposite fabricated via co-precipitation method. Separation Science and Technology, 54(16), 2682-2694.

\section{https://doi.org/10.1080/01496395.2018.1550513}

Konuklu, Y., \& Paksoy, H. Ö. (2011). Faz Değiştiren Maddeler İle Binalalarda Enerji Verimliliği. X. Ulusal Tesisat Mühendisliği Kongresi, 919-930.

La Rosa, A. D., Greco, S., Tosto, C., \& Cicala, G. (2021). LCA and $\mathrm{LCC}$ of a chemical recycling process of waste $\mathrm{CF}$ thermoset composites for the production of novel CFthermoplastic composites. Open loop and closed loop scenarios. Journal of Cleaner Production, 304, 127158. https://doi.org/10.1016/j.jclepro.2021.127158

Llantoy, N., Chàfer, M., \& Cabeza, L. F. (2020). A comparative life cycle assessment (LCA) of different insulation materials for buildings in the continental Mediterranean climate. Energy and Buildings, 225, 110323. https://doi.org/10.1016/j.enbuild.2020.110323

Manjunatha, M., Preethi, S., Malingaraya, Mounika, H. G., Niveditha, K. N., \& Ravi. (2021). Life cycle assessment (LCA) of concrete prepared with sustainable cement-based materials. Materials Today: Proceedings, 47, 3637-3644. https://doi.org/10.1016/j.matpr.2021.01.248

Marcelino-Sadaba, S., Kinuthia, J., Oti, J., \& Seco Meneses, A. (2017). Challenges in Life Cycle Assessment (LCA) of stabilised clay-based construction materials. Applied Clay Science, 144(May),

121-130.

https://doi.org/10.1016/j.clay.2017.05.012

Monahan, J., \& Powell, J. C. (2011). An embodied carbon and energy analysis of modern methods of construction in housing: A case study using a lifecycle assessment framework. Energy and Buildings, 43(1), 179-188. https://doi.org/10.1016/j.enbuild.2010.09.005

Morris, F., Allen, S., \& Hawkins, W. (2021). On the embodied carbon of structural timber versus steel, and the influence of LCA methodology. Building and Environment, 206(May), 108285. https://doi.org/10.1016/j.buildenv.2021.108285

Murmu ve Patel, (2018). Sürdürülebilir Tuğla Üretimine Doğru: Genel Bakış Konstr. İnşa Etmek. Anne, 165, 112-125, 10.1016/j.conbuildmat.2018.01.038

Najjar, M., Figueiredo, K., Palumbo, M., \& Haddad, A. (2017). Integration of BIM and LCA: Evaluating the environmental impacts of building materials at an early stage of designing a typical office building. Journal of Building Engineering, 14(March),

$115-126$ https://doi.org/10.1016/j.jobe.2017.10.005

Oztas Karaman S., \& Tanaçan, L. (2015). Verification of Life Cycle Impact Assessment Model developed for Turkish Building Materials Sector. The 2nd International International Sustainable Building Symposium, 866-874.

Özcan, H.K., Şahin, Ü., Bayat, C. \& Uçan, O.N (2006). İstanbul İli Tropsoferik Ozon (O3) Konsantrasyonlarının Hücresel Yapay Sinir Ağ Yöntemiyle Modellenmesi. Gazi Üniv. Müh. Mim. Fak. Der. 21(2), 239-245

Özdemir, A. (2019). Eskişehir Teknik Üniversitesi Bilim ve Teknoloji Dergisi B- Teorik Bilimler. 7(2), 166-183. https://doi.org/10.20290/estubtdb.517254

Özutku, O., \& Karakuş, C. Binalarda Isı Yalıtım Yolu İle Enerji Tasarrufunun İklimlendirme Açısından İncelenmesi Ve Optimum Cam Kaplama Alanı Belirlenmesi. http://www1.mmo.org.tr/resimler/dosya_ekler/f26d91da3dfa 79e_ek.pdf

Pannier, M. L., Lemoine, C., Amiel, M., Boileau, H., Buhé, C., \& Raymond, R. (2021). Multidisciplinary post-occupancy evaluation of a multifamily house: An example linking sociological, energy and LCA studies. Journal of Building Engineering, 37(July https://doi.org/10.1016/j.jobe.2020.102139 
Peuportier, B., Thiers, S., \& Guiavarch, A. (2013). Eco-design of buildings using thermal simulation and life cycle assessment. Journal of Cleaner Production, 39, 73-78. https://doi.org/10.1016/j.jclepro.2012.08.041

Rajagopalan, N., Bilec, M. M., \& Landis, A. E. (2010). Residential life cycle assessment modeling: Comparative case study of insulating concrete forms and traditional building materials. Journal of Green Building, 5(3), 95-106. https://doi.org/10.3992/jgb.5.3.95

Raposo, C., Rodrigues, F., \& Rodrigues, H. (2019). BIM-based LCA assessment of seismic strengthening solutions for reinforced concrete precast industrial buildings. Innovative Infrastructure Solutions, 4(1), 1-10. https://doi.org/10.1007/s41062-019-0239-7

Salazar, J. (2013). Life cycle assessment (LCA) of windows and window materials. Eco-Efficient Construction and Building Materials: Life Cycle Assessment (LCA), Eco-Labelling and Case Studies, 502-527. https://doi.org/10.1533/9780857097729.3.502

Selici. T., Utlu Z. ve İlten N. (2005). Enerji Kullanımının Çevresel Etkileri Ve Sürdürülebilir Gelişme Açısından Değerlendirilmesi.

Sezer, F. Ş., \& Dilmaç, Ş. (2014). Farklı Duvar Malzemesi ve Yalıtım Uygulamalarının Isıl Davranışlarının Deneysel Olarak İncelenmesi. Experimental Study on the Effects of Wall Materials and Insulation Conditions on the Thermal Behavior (Vol. 29, Issue 2). https://dergipark.org.tr/tr/download/article-file/211241

Thiel, C., Stengel, T., \& Gehlen, C. (2013). Life cycle assessment (LCA) of road pavement materials. In Eco-Efficient Construction and Building Materials: Life Cycle Assessment (LCA), Eco-Labelling and Case Studies. https://doi.org/10.1533/9780857097729.2.368

Tindale, A. (2005). DesignBuilder Software, Retrieved 29 April, 2005.

Tuna, M. (2015). Y.D.D. Yöntemi Kapsamında Yün Ve Plastik Esaslı Halı Kaplamalarının Çevresel Performansının Değerlendirilmesi ve İç Mekân Hava Kalitesine Etkileri. TESKON.

Tuna Taygun, G. (2005). Yapı Ürünlerinin Yaşam Döngüsü Değerlendirmesine Yönelik Bir Model Önerisi. Doktora Tezi, Yıldız Teknik Üniversitesi Fen Bilimleri Enstitüsü, İstanbul, $213 \mathrm{~s}$.

Tushar, Q., Bhuiyan, M. A., Zhang, G., \& Maqsood, T. (2021). An integrated approach of BIM-enabled LCA and energy simulation: The optimized solution towards sustainable development. Journal of Cleaner Production, 289, 125622. https://doi.org/10.1016/j.jclepro.2020.125622

UNFCCC-United Nations Climate Change,2020). https://di.unfecc.int/detailed_data_by party

URL 1 : https://passipedia.org/_media/picopen/9f_160815 phi build ing_criteria_en.pdf

URL 2 :

https://www.google.com/url?sa=i\&url=https $\% 3 \mathrm{~A} \% 2 \mathrm{~F} \% 2 \mathrm{Ft}$ witter.com $\% 2$ Femlakyonetim $\% 2$ Fstatus $\% 2$ F 109278529463
2542209\%3Flang\%3Dde\&psig=AOvVaw0JVIoI4hYTUIya ghOXLBt7\&ust $=1623415462699000 \&$ source $=$ images \&cd $=$ vfe\&ved=0CAIQjRxqFwoTCLCupISMjfECFQAAAAAdA AAAABAy

URL 3 : https://www.htflux.com/en/

Valencia-Barba, Yovanna E., \& Gómez-Soberón, J. M. (2019). LCA Analysis of Three Types of Interior Partition Walls Used in Buildings. Proceedings, 2(22), 1595. https://doi.org/10.3390/proceedings2221595

Valencia-Barba, Yovanna Elena, Gómez-Soberón, J. M., GómezSoberón, M. C., \& Rojas-Valencia, M. N. (2021). Life cycle assessment of interior partition walls: Comparison between functionality requirements and best environmental performance. Journal of Building Engineering, 44. https://doi.org/10.1016/j.jobe.2021.102978

Yıldız, A., Gürlek, G., Erkek, M., \& Özbalta, N. (2008). Yapılarda Isı Yalıtım Kalınlığının Ekonomik ve Çevresel Analizi. Is Bilimi ve Tekniği Dergisi, 28(2), 25-34.

Yılmaz, E., Arslan, H., \& Bideci, A. (2019). Environmental performance analysis of insulated composite facade panels using life cycle assessment (LCA). Construction and Building Materials, 202, 806-813. https://doi.org/10.1016/j.conbuildmat.2019.01.057

Yildiz, Y., Özbalta, T. G., \& Arsan, Z. D. (2011). Farklı Cam Türleri ve Yönlere Göre Pencere/Duvar Alanı Oranının Bina Enerji Performansına Etkisi: Eğitim Binası, İzmir. Megaron, 6(1).

https://jag.journalagent.com/megaron/pdfs/MEGARON 6 130 38.pdf

Wu, T., Gong, M., \& Xiao, J. (2020). Preliminary sensitivity study on an life cycle assessment (LCA) tool via assessing a hybrid timber building. Journal of Bioresources and Bioproducts, 5(2), 108-113. https://doi.org/10.1016/j.jobab.2020.04.004 